\title{
RADIASI BENDA HITAM DAN EFEK FOTOLISTRIK SEBAGAI KONSEP KUNCI REVOLUSI SAINTIFIK DALAM PERKEMBANGAN TEORI KUANTUM CAHAYA
}

\author{
Sutarno $^{1 \star}$, Erwin ${ }^{2}$, dan Muhammad Syaipul Hayat ${ }^{3}$ \\ ${ }^{1}$ Program Studi Pendidikan Fisika, Fakultas Keguruan dan IImu Pendidikan, Universitas Bengkulu \\ ${ }^{2}$ Sekolah Tinggi Keguruan dan IImu Pendidikan Nurul Huda, Sukaraja, OKU Timur, Sumatera Selatan \\ 3Universitas PGRI Semarang \\ *E-mail: m.sutarno@unib.ac.id
}

\begin{abstract}
Abstrak
Teori fisika klasik telah menghasilkan konsensus bahwa cahaya merupakan gelombang elektromagnetik yang terdistribusi secara malar dalam ruang tiga dimensi. Cahaya merambat transversal dengan laju energi sebanding dengan intensitasnya. Paradigma ini telah menuntun rangkaian aktivitas ilmiah pada sains normal yang menghasilkan berbagai perkembangan ilmu pengetahuan. Teori gelombang elektromagnetik terus berkembang hingga awal abad 19 sebelum akhirnya gagal menjelaskan fakta spektrum radiasi benda hitam dan efek fotolistrik. Teori fisika klasik mengalami krisis. Fase ini mendorong para ilmuwan melakukan berbagai spekulasi teori dan eksperimen guna memperoleh penyelesaian masalah. Muncul pemikiran revolusioner yang diilhami oleh gagasan Planck yang selanjutnya diartikan lebih fisis oleh Einstein membentuk teori kuantum cahaya. Fenomena radiasi benda hitam dan efek fotolistrik dapat dijelaskan secara memuaskan hanya dengan menganggap bahwa cahaya tidak terdistribusi secara malar, melainkan dalam bentuk paket-paket energi yang disebut kuanta (foton). Besar energi foton tidak ditentukan oleh intensitas, melainkan oleh frekuensi cahaya. Fenomena radiasi benda hitam dan efek fotolistrik telah membuka gerbang pergeseran paradigma, dari fisika klasik menuju fisika modern.
\end{abstract}

Kata kunci: Radiasi benda hitam, Efek fotolistrik, Revolusi saintifik, Teori kuantum cahaya.

\section{PENDAHULUAN}

Fisika merupakan ilmu yang mempelajari gejala alam tak hidup (materi) dalam lingkup ruang dan waktu. Fisikawan mempelajari perilaku dan sifat materi dalam bidang yang sangat beragam, mulai dari partikel submikroskopis yang membentuk segala materi hingga perilaku materi alam semesta sebagai satu kesatuan kosmos. Sejarah fisika sepanjang yang telah diketahui dimulai pada tahun 2400 SM, ketika kebudayaan Harappan menggunakan suatu benda untuk memperkirakan dan menghitung sudut bintang di angkasa. Sejak saat itu fisika terus berkembang sampai sekarang. Revolusi ilmu yang terjadi sekitar tahun 1600 dapat dikatakan menjadi batas antara pemikiran purba dan lahirnya paradigma fisika klasik. Selanjutnya, revolusi fisika kembali terjadi dalam kisaran tahun 1900 yang menandai dimulainya era baru fisika yaitu era fisika modern.

Periode fisika klasik terjadi dalam rentang tahun 1600 hingga 1890an. Pada periode ini, konsepkonsep fisika yang mendasar berhasil diformulasikan. Pemahaman keilmuan masih cenderung sempit dan perkembangannya tidak seluas perkembangan konsep-konsep fisika modern. Contoh-contoh pemikiran pada periode ini adalah mekanika Newtonian, elektrodinamika klasik (melahirkan Hukum Ohm, Hukum Faraday, Teori Maxwell, dan lain-lain), dan termodinamika klasik (melahirkan hukum kekekalan energi, teori relativitas umum).

Periode fisika modern dimulai dari tahun 1900 hingga saat ini. Lahirnya fisika modern terutama ditandai dengan ditemukan beberapa fenomena yang tidak dapat dijelaskan menggunakan teori fisika klasik. Dua fenomena terkenal yang gagal dijelaskan menggunakan landasan fisika klasik adalah fenomena radiasi benda hitam dan efek fotolistrik. Teori gelombang elektromagnetik yang menjadi paradigma sentral perilaku cahaya dalam fisika klasik tidak mampu memberikan penjelasan terkait fakta-fakta teramati dalam kasus radiasi benda hitam dan efek fotolistrik. Teori gelombang elektromagnetik Maxwell yang meyakini bahwa cahaya terdistribusi secara malar dalam bentuk 
gelombang elektromagnetik menemui jalan buntu. Paradigma fisika klasik mengalami krisis.

Banyak upaya yang dilakukan para ilmuwan untuk mengatasi krisis yang terjadi. Beberapa ilmuwan mencoba kembali pada cara-cara ilmiah yang lama sambil memperluas cara-cara tersebut untuk menghadirkan eksplanasi yang memuaskan. Beberapa ilmuwan lainnya mencoba mengembangkan paradigma tandingan yang bisa memecahkan masalah dan membimbing pada riset berikutnya. Kesadaran akan adanya malafungsi terkait fenomena radiasi benda hitam dan efek fotolistrik mendorong lahirnya revolusi dalam fisika. Sejarah mencatat bahwa revolusi ini ditandai dengan lahirnya teori kuantum cahaya yang secara memuaskan mampu memberikan penjelasan dan prediksi terkait radiasi benda hitam dan efek fotolistrik. Dalam perkembangannya, teori kuantum cahaya menuntun para ahli pada riset-riset lanjutan hingga dicetuskannya teori dualisme gelombang cahaya yang sangat fenomenal. Fenomena radiasi benda hitam dan efek fotolistrik dapat dipandang sebagai konsep kunci lahirnya revolusi sains dalam perkembangan fisika modern.

\section{Revolusi Saintifik}

\section{HASIL DAN PEMBAHASAN}

Pergeseran paradigma (paradigm shift) adalah istilah yang cocok untuk menggambarkan terjadinya dimensi kreatif pikiran manusia dalam bingkai pengetahuan. Pergeseran paradigma merupakan letupan ide yang merangsang timbulnya letupan ide-ide lain, terjadi terus-menerus, sambung menyambung, baik pada orang yang sama maupun orang yang berbeda. Reaksi berantai ini pada akhirnya menjadi kekuatan yang bisa merubah wajah dan tatanan dunia serta peradaban manusia ke arah suatu kemajuan ilmu pengetahuan (Hamdani, 2011).

Revolusi sains merupakan episode perkembangan non-kumulatif, dimana paradigma lama diganti sebagian atau seluruhnya oleh paradigma baru yang ber-tentangan (Kuhn, 1989). Transformasitransformasi paradigma yang berurutan dari paradigma yang satu ke paradigma yang lainnya melalui revolusi merupakan pola perkembangan yang biasa dari sains yang telah matang. Menurut Kuhn (1989), sains berkembang melalui pergeseran paradigma, yakni perubahan fundamental dalam asumsi, teori, dan metode dalam bingkai paradigma lama ke asumsi, teori dan metode dalam bingkai paradigm baru. Lebih lanjut, Kuhn menyatakan bahwa ilmu pengetahuan berkembang secara revolusioner dari satu paradigma ke paradigma lainnya melalui beberapa fase perkembangan, yaitu fase preparagdimatic, competing paradigm, supremacy of one paragdigm, normal science, crisis, dan paradigm shift/new paradigm (Firman, 2016).

\section{a. Fase Pra-Paradigma}

Fase pra-paradigma disebut juga dengan fase immature science. Pada fase ini penelitianpenelitian keilmuan mengenai hal-hal tertentu dilakukan tanpa arah dan tujuan tertentu. Berbagai macam aliran pemikiran muncul, saling bersaing, dan meniadakan satu sama lain. Pemikiranpemikiran tersebut memiliki konsepsi yang berbeda mengenai masalah-masalah dasar disiplin ilmu dan kriteria apa yang harus digunakan untuk mengevaluasi teori-teori. Pada fase ini, belum terbentuk suatu paradigma tunggal yang secara langsung mendefinisikan ilmu pengetahuan dan mengatur praktek-praktek ilmiahnya (Nahrul, 2010).

\section{b. Persaingan Paradigma}

Agar dapat membentuk ilmu pengetahuan, sebuah disiplin ilmu harus mencapai suatu konsensus yang berada dalam naungan satu paradigma tertentu. Diantara berbagai sains yang berkembang pada fase pra-paradigma, akan muncul salah satu aliran pemikiran atau teori yang kemudian mendominasi disiplin-disiplin ilmu lainnya. Aliran pemikiran lainnya berkiblat dan mengakui superioritas aliran pemikiran yang dominan tersebut. Aliran pemikiran ini menjanjikan pemecahan masalah yang lebih akurat dan masa depan penelitian yang lebih maju sehingga ia lebih dominan dibanding pesaingnya.

\section{c. Fase Sains Normal}

Ketika suatu konsensus dicapai, Kuhn mengklaim bahwa para saintis telah mulai menyentuh sains normal. Prasyarat sains normal adalah adanya komitmen terhadap suatu paradigma 
bersama yang akan menentukan aturan main dan menjadi tolok ukur standar dalam praktek ilmiah. Saintis normal (normal scientis) tidak akan membuat penemuan-penemuan baru di luar paradigma yang berlaku. Sebaliknya, mereka sepenuhnya terlibat dalam penggunaan paradigma tersebut untuk lebih memahami gejala-gejala alam secara lebih mendetail.

Menurut Kuhn, sains normal merupakan suatu aktualisasi ilmu pengetahuan yang bisa menjawab persoalan-persoalan yang muncul pada masa tertentu. Sains normal dianalogikan sebagai suatu aktivitas memecahkan teka teki (puzzle). Saintis bekerja didalam pandangan dunia yang sudah mapan. IImu bukan merupakan upaya untuk menemukan obyektivitas dan kebenaran, melainkan lebih menyerupai upaya pemecahan masalah di dalam pola-pola keyakinan yang telah berlaku (Kuhn, 1989). Selama melakukan penelitian, para ilmuan terikat oleh beberapa hukum, teori, bahasa, hipotesa dari paradigma. Seluruh aktivitas ilmiah sains normal merupakan cerminan bagaimana suatu paradigma diartikuasi. Pada fase ini, ilmuwan tidak bersikap kritis terhadap paradigma yang membimbing aktifitas ilmiahnya, tidak mempertanyakan prinsip-prinsip fundamental dalam disiplin ilmunya (Firman, 2016). Akumulasi pengetahuan dalam sains normal mengokohkan paradigma yang didukung, sampai didapati fakta-fakta yang tidak bersesuaian dengan teori-teori dominan yang diyakini banyak ilmuwan.

\section{d. Fase Anomali dan Krisis}

Fase anomali dan krisis disebut juga fase munculnya extraordinary science (Nahrul, 2010). Pada masa ini, ilmu pengetahuan, baik dalam praktik ilmiah maupun matriks-matriks disipliner tidak dapat lagi diandalkan dalam memecahkan persoalan yang muncul. Munculnya masalah krusial dan tak terpecahkan tidak hanya membuat para ilmuwan mengalami kebingungan, namun juga melahirkan krisis dalam suatu komunitas ilmiah. Mulai saat itulah paradigma yang berlaku selama ini dipertanyakan kredebilitasnya.

Berbagai anomali yang muncul dalam komunitas ilmiah mendorong terbentuknya polaritas ilmuwan yang saling bersaing dalam membentuk strategi-strategi untuk memecahkan masalah yang sedang mereka hadapi. Masing-masing kelompok menggunakan paradigmanya sendiri untuk argumentasi dalam membela paradigma itu. Terjadi persaingan yang serius, konsekuensinya adalah siapa yang menang tentu dialah yang akan menentukan keberlakuan suatu paradigma. Masa inilah yang disebut Kuhn sebagai periode kekacauan profesional ( $a$ periode of pronounced proffesional insecurity) atau dalam kata lain disebut masa krisis. Menurut Yeremias (2012), kakteristik utama dalam masa krisis ditandai dengan adanya proliferasi teori. Respon masyarakat pada masa krisis ini tidak sampai pada titik meninggalkan paradigma, melainkan berusaha mencari solusi untuk mengatasi anomali yang ada dalam rangka mempertahankan penggunaan paradigma yang berlaku.

Selama fase extraordinaty science, para saintis melakukan penelitian secara acak, bereksperiman untuk melihat efek yang akan terjadi setelahnya, dan mencari efek yang secara alamiah tak bisa terprediksi olehnya. IImuwan dalam masa krisis akan terus mencoba untuk menghasilkan spekulasi teori, jika berhasil maka ia akan membuka jalan menuju paradigma baru.

\section{e. Fase Munculnya Paradigma Baru}

Selama persaingan masa krisis, akan muncul salah satu aliran pemikiran yang dapat mengatasi masalah-masalah sains, dan kemudian mampu menggeneralisasi serta menjanjikan masa depan penelitian ilmiah yang lebih baik. Paradigma baru yang terbentuk dipandang lebih mampu menyelesaikan anomali-anomali daripada paradigma lama. Pada titik inilah extraordinary science kembali menjadi sains normal. Perubahan tersebut merupakan titik klimaks dari revolusi ilmu pengetahuan. Kuhn memaknai rangkaian tersebut sebagai "episode perkembangan non-kumulatif dimana sebuah paradigma yang lebih tua diganti secara keseluruhan atau sebagian oleh paradigma baru yang lebih kompatibel." Paradigma baru akan menghasilkan teori-teori baru yang diperlukan untuk memecahkan permasalahan dan anomali dalam hubungannya dengan teori yang ada tentang alam. Teori baru yang dihasilkan harus memungkinkan prakiraan-prakiraan yang 
berbeda dari yang diturunkan oleh teori pendahulunya (Kuhn, 1989).

Hampir seluruh kosa kata, istilah-istilah, konsep-konsep, idiom-idiom, cara penyelesaian persoalan, cara berfikir, dan cara mendekati persoalan berubah dengan sendirinya setelah terjadi revolusi. Perangkat lama yang mungkin masih relevan untuk difungsikan tetap tidak dikesampingkan. Namun jika cara pemecahan persoalan model lama sudah tidak dapat digunakan untuk memecahkan persoalan yang datang kemudian, maka secara otomatis dibutuhkan seperangkat cara, rumusan dan wawasan yang sama sekali baru untuk memecahkan persoalanpersoalan baru.

Salah satu dampak utama dari revolusi sains adalah perubahan pandangan dunia (world view) yang menaungi para ilmuwan dalam seluruh aktivitas ilmiah mereka. Hasilnya adalah perubahan paradigma yang menyebabkan para ilmuwan melihat dunia mereka secara berbeda. Paradigma baru ini selanjutnya akan menjadi fase sains normal sampai terjadinya keadaan anomali dan krisis paradigma berikutnya yang akan melahirkan paradigma baru, dan seterusnya. Jadi, menurut Kuhn ilmu berkembang melalui siklus-siklus, sains normal diikuti oleh revolusi, yang diikuti lagi oleh sains normal, dan kemudian diikuti lagi oleh revolusi.

Proses revolusi sains menuju sains normal bukanlah jalan bebas hambatan. Sebagian ilmuwan atau masyarakat sains tertentu ada kalanya tidak mau menerima paradigma baru. Hal ini menimbulkan masalah sendiri yang memerlukan pemilihan dan legitimasi paradigma yang lebih definitif. Para ilmuwan yang tidak mau menerima paradigma baru sebagai landasan risetnya akan tetap bertahan pada paradigma yang telah dibongkar dan sudah tidak mendapat dukungan dari mayoritas masyarakat sains, maka aktivitas-aktivitas risetnya hanya merupakan tautologi yang tidak bermakna (Zubaedi, 2007).

\section{Radiasi Benda Hitam dan Bencana Ultraviolet}

Benda hitam (black body) didefinisikan sebagai benda yang menyerap semua radiasi yang datang padanya. Benda hitam ideal dimodelkan dengan sebuah rongga hitam dengan lubang kecil. Bila berkas cahaya memasuki rongga melalui lubang tersebut, berkas cahaya akan dipantulkan berkali-kali pada dinding rongga tanpa sempat keluar lagi melalui lubang. Energi cahaya akan diserap oleh dinding rongga setiap kali terjadi pemantulan. Radiasi benda hitam merupakan radiasi elektromagnetik yang dipancarkan oleh benda hitam. Spektrum radiasi benda hitam pada beberapa temperature (T) ditunjukkan pada Gambar 1.

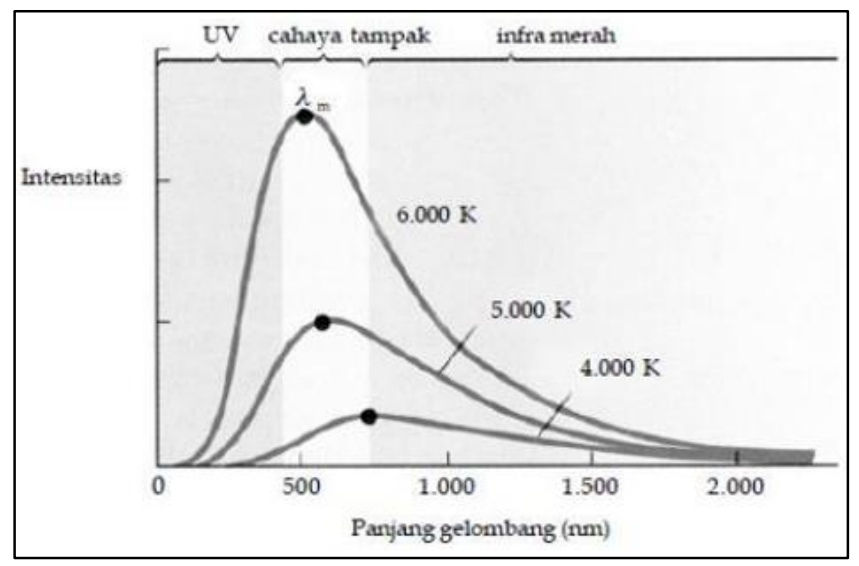

Gambar 1. Kurva spektrum radiasi benda hitam

Pada tahun 1879 Stefan-Boltzmann melakukan eksperimen untuk mengetahui karakter universal dari radiasi benda hitam. Mereka menemukan bahwa daya total per satuan luas (intensitas) yang dipancarkan pada semua frekuensi oleh benda hitam panas adalah sebanding dengan pangkat empat dari suhu mutlaknya, $I=e \sigma T^{4}$. Total energi radiasi yang dipancarkan sebanding dengan luas daerah 
di bawah grafik pada suhu tetap, yaitu sebesar $E=e \sigma T^{4}$. Tampak bahwa besar energi radiasi sebanding dengan intensitas yang dihasilkan. Persamaan tersebut dikenal sebagai Hukum StefanBoltzmann (Gie et al, 1999).

Spektrum radiasi benda hitam selanjutnya diselidiki oleh Wien. Menurut Wien, jika dipanaskan terus menerus, benda hitam akan memancarkan radiasi kalor yang puncak spektrumnya memberikan warna-warna tertentu. Warna spektrum bergantung pada panjang gelombangnya, dan panjang gelombang ini akan bergeser sesuai suhu benda, seperti ditunjukkan pada Gambar 1. Jika suatu benda dipanaskan maka benda akan memancarkan radiasi kalor. Pada suhu rendah, radiasi yang dipancarkan memiliki intensitasnya rendah sehingga tidak ada cahaya radiasi yang terlihat. Jika suhu terus dinaikkan, benda mula-mula akan berpijar merah, selanjutnya akan berwarna kuning keputihputihan.

Wien memformulasikan bahwa panjang gelombang pada puncak spektrum berbanding terbalik dengan suhu mutlak benda, $\lambda_{\mathrm{m}}=\mathrm{C} / \mathrm{T}$, dengan $\mathrm{C}$ merupakan konstanta pergeseran Wien. Berdasarkan kurva pada Gambar 1, terlihat bahwa dengan naiknya suhu, puncak-puncak spektrum bergeser ke arah panjang gelombang yang semakin kecil. Namun demikian, formulasi yang diperoleh Wien ternyata tidak sesuai dengan data hasil eksperimen. Formulasi Wien hanya mampu memprediksi spektrum radiasi pada daerah dengan panjang gelombang kecil, dan tidak mampu memberikan gambaran spektrum radiasi pada daerah dengan panjang gelombang besar.

Ketidak akuratan formula Wien mendorong Reyleigh-Jeans untuk mengembangkan gagasangagasan lain. Dengan berpijak pada teori gelombang elektromagnetik, Reyleigh-Jeans mendapatkan bahwa jika osilator-osilator pada dinding rongga benda hitam berada pada kesetimbangan, maka rapat energi radiasi persatuan volume diperoleh sebesar $E_{\lambda}=8 \pi k T / \lambda^{4}$. Namun formulasi Reyleigh-Jeans juga tidak sepenuhnya sesuai dengan data hasil eksperimen. Formulasi Reyleigh-Jeans hanya cocok untuk daerah dengan panjang gelombang besar dan tidak cocok untuk daerah dengan panjang gelombang pendek, yaitu pada daerah sinar ultraviolet (UV). Fenomena ini dikenal dengan istilah "bencana ultraviolet" (Gie et al, 1999). Formulasi Reyleigh-Jeans memberikan prediksi bahwa besar energi radiasi akan tak berhingga pada daerah dengan panjang gelombang kecil (daerah ultraviolet). Hal ini memberikan konsekuensi bahwa bumi kita akan sangat panas mengingat bumi selalu dipenuhi oleh sinar ultraviolet yang memiliki energi atau intensitas tak berhingga. Namun kenyataannya hal tersebut tidaklah terjadi.

Pada tahun 1900, Planck membuat suatu gagasan baru tentang sifat dasar dari getaran molekulmolekul pada dinding rongga benda hitam (pada saat itu elektron belum ditemukan). Gagasan tersebut sangat radikal dan bertentangan dengan teori fisika klasik, yaitu: (1) radiasi yang dipancarkan oleh getaran molekul tidaklah kontinu tetapi dalam paket-paket energi diskret yang disebut kuanta (foton). Besar energi setiap foton ditentukan oleh frekuensi getaran, $E=h v$, sehingga untuk $n$ buah foton maka energinya dinyatakan oleh $E_{n}=n h v$ dengan $\mathrm{n}$ merupakan bilangan asli. Energi dari molekul-molekul dikatakan terkuantisasi dan energi yang diperkenankan disebut tingkat energi. (2) Molekul-molekul memancarkan atau menyerap energi foton apabila "melompat" dari satu tingkat energi ke tingkat energi lainnya. Jika molekul tetap tinggal dalam satu tingkat energi tertentu, maka tidak ada energi yang diserap atau dipancarkan molekul.

Melalui kedua asumsi yang fenomenal ini, Planck dapat memformulasikan spektrum radiasi benda hitam yang cocok untuk semua panjang gelombang, yaitu:

$$
E(v)=\frac{8 \pi v^{2}}{c^{3}} \frac{h v}{e^{h v / k T}-1}
$$

dengan $h$ adalah tetapan Planck, $c$ adalah cepat rambat cahaya, $k$ adalah tetapan Boltzman, dan $T$ adalah suhu mutlak benda hitam. Gagasan Planck ini merupakan cikal bakal bagi lahirnya teori kuantum cahaya yang dikemukakan oleh Einstein pada beberapa tahun kemudian (Beiser, 1981).

\section{Efek Fotolistrik dan Teori Kuantum Cahaya}


Gejala fotolistrik merupakan munculnya arus listrik akibat permukaan suatu bahan logam disinari. Arus listrik yang muncul merupakan arus elektron bermuatan negatif. Sinar yang datang dipermukaan bahan menyebabkan elektron tereksitasi. Gejala efek fotolistrik telah dikenal sejak lama. Pada tahun 1887 Hallwach mengamati bahwa pelat yang dilapisi seng yang bermuatan negatif kehilangan muatannya jika disinari ultraviolet (Gie et al, 1999). Teori fisika klasik berusaha memberikan penjelasan terkait fakta ini. Menurut teori gelombang elektromagnetik, intensitas merupakan kerapatan laju energi cahaya. Jika intensitas cahaya yang datang pada permukaan bahan makin besar, maka laju energi (energi per detik yang datang pada permukaan bahan) juga semakin besar, dengan demikian jumlah elektron yang dipancarkan seharusnya semakin besar. Selain itu, elektron akan tereksitasi dari pelat bila intensitas cahanya cukup, berapapun frekuensi sinar yang digunakan.

Gejala fotolistrik selanjutnya diamati oleh Lenard pada tahun 1902. Lenard menemukan bahwa jika pelat (seng) disinari dengan sinar ultraviolet, maka elektron akan lepas dan meninggalkan pelat dengan fakta-fakta: (1) kecepatan elektron yang lepas dari seng tidak bergantung pada intensitas cahaya, tetapi hanya bergantung pada frekuensi (atau panjang gelombang) sinar yang digunakan, (2) pada logam tertentu, tak terdapat pancaran elektron jika frekuensi cahaya yang digunakan lebih kecil dari suatu frekuensi tertentu. Berdasarkan hasil eksperimen juga diketahui bahwa elektron tidak dapat dipancarkan pada sembarang nilai panjang gelombang (frekuensi), meskipun intensitasnya dibuat besar (Krane, 1992). Fenomena yang teramati oleh Lenard sangat bertentangan dengan teori fisika klasik. Fakta-fakta yang teramati sama sekali berbeda dengan eksplanasi fisika klasik.

Teori kuantisasi energi yang dikemukakan oleh Planck, kemudian diartikan lebih fisis oleh Einstein dan digunakan untuk menjelaskan hasil eksperimen dari gejala fotolistrik. Pada tahun 1905 Einstein mulai memperkenalkan teori kuantum cahaya. Menurut Einstein, pancaran cahaya berfrekuensi $v$ berisi paket-paket gelombang atau paket-paket energi. Energi yang dibawa setiap paket gelombang adalah sebesar $h v$. Cahaya terdiri atas paket-paket energi yang disebut foton. Jumlah foton per satuan luas penampang per satuan waktu sebanding dengan intensitas cahaya, tetapi energi foton tidak bergantung pada intensitas cahaya. Energi foton hanya bergantung pada frekuensi gelombang cahaya (Beiser, 1981).

Menurut postulat Planck, foton-foton yang sampai pada katoda akan diserap sebagai kuantum energi. Ketika elektron menyerap foton, maka elektron memperoleh sejumlah energi yang dibawa foton yaitu sebesar $h v$. Energi yang diterima ini sebagian digunakan elektron untuk melepaskan diri dari bahan dan sisanya digunakan untuk bergerak, menjadi energi kinetik elektron. Besarnya energi yang diperlukan oleh elektron untuk melepaskan diri dari bahan (melawan energi ikatan elektron dalam bahan) disebut fungsi kerja ( $W_{\circ}$ ) (Beiser, 1981). Besar energi kinetik elektron foto diungkapan dalam persamaan $E_{k}=h f-W_{o}$, disebut persamaan fotolistrik Einstein.

Kesahihan penafsiran Einstein mengenai fotolistrik diperkuat dengan ditemukannya emisi termionik menjelang abad ke-19, yaitu terjadinya emisi elektron dari benda panas. Emisi termionik memungkinkan bekerjanya piranti seperti tabung televisi yang di dalamnya terdapat filamen logam yang pada temperatur tinggi mampu menghasilkan arus elektron. Jelaslah bahwa elektron yang terpancar memperoleh energi dari agitasi termal pada filamen. Elektron memperoleh energi minimum tertentu sehingga dapat tereksitasi. Pada kasus emisi fotolistrik, foton cahaya menyediakan energi yang diperlukan oleh elektron untuk lepas, sedang dalam emisi termionik kalorlah yang menyediakannya. Dalam kedua kasus itu, proses fisis yang berhubungan dengan eksitasi elektron dari permukaan logam adalah sama.

Fisikawan Amerika Robert Millikan tidak dapat begitu saja menerima teori Einstein. Penafsiran Einstein dipandang sebagai serangan terhadap teori gelombang elektromagnetik cahaya. Milikan bekerja selama sepuluh tahun untuk mengkonfirmasi penafsiran Einstein dalam kasus fenomena efek fotolistrik melalui berbagai seting eksperimen. Namun ia gagal menemukan fakta yang mampu menyanggah penafsiran Einsten. Milikan justru mendapatkan berbagai fakta yang memperkuat prilaku cahaya sebagai partikel. Secara eksperimental sahihnya teori kuantum itu dibuktikan oleh Millikan pada tahun 1914. Millikan menemukan hubungan linear antara tegangan pemberhenti elektron dan frekuensi 
cahaya yang mendesak elektron pada bahan katoda tertentu. Pada tahun 1921 Albert Einstein memperoleh hadian Nobel atas keberhasilannya menerangkan gejala efek fotolistrik.

Inilah ikhwal lahirnya fisika modern yang menampik asumsi teori-teori mapan saat itu, salah satunya adalah teori gelombang elektromagnetik Maxwell yang telah berhasil memadukan fenomena kelistrikan dan kemagnetan dalam satu formula. Dibutuhkan waktu cukup lama untuk meyakinkan komunitas fisika bahwa cahaya memiliki sifat granular. Nyatanya Millikan membutuhkan hampir 11 tahun untuk membuktikan kebenaran hipotesis Einstein. Tujuh tahun kemudian Arthur Compton berhasil melakukan eksperimen yang membuktikan sekaligus mengukuhkan sifat kuantum cahaya.

\section{Tinjauan Revolusi Saintifik pada Fenomena Radiasi Benda Hitam dan Efek Fotolistrik}

Kegagalan fisika klasik dalam menjelaskan fenomena bencana ultraviolet dan efek fotolistrik merupakan sebuah "tamparan" besar bagi para ilmuwan saat itu. Paradigma fisika klasik mengalami krisis. Pada masa tersebut, ilmuwan terus mencoba menghasilkan spekulasi teori. Berbagai aktivitas ilmiah dilakukan untuk memberikan jawaban atas permasalahan. Sebagian ilmuwan melakukan tindakan ilmiah dengan tetap mengacu pada paradigma lama sambil melakukan beberapa perubahan untuk memperoleh jawaban terbaik. Sebagian lagi berusaha membentuk cara berpikir baru melalui pendekatan-pendekatan baru.

Formulasi yang diberikan oleh Wien, Stefan-Boltzman, Reyleigh-Jeans dengan tetap berpijak pada teori fisika klasik untuk menjelaskan anomali spektrum radiasi benda hitam, dan eksperimen panjang yang dilakukan Milikan untuk menyanggah teori kuantum cahaya Einstein, merupakan bukti kuat bahwa ilmuwan saat itu tidak mau begitu saja menerima teori yang sama sekali baru bagi mereka. Kenyataannya, pemikiran revolusioner Plank dan Einstein telah menimbulkan ketakutan dan keraguan dalam diri banyak orang (misalnya pada diri Reyleigh-Jeans dan Milikan), namun berdampak amat penting bagi perkembangan ilmu pengetahuan. Hal ini bersesuaian dengan apa yang dikatakan oleh Kuhn, bahwa kritik-kritik revolusioner acapkali memberikan dampak emosional yang amat besar pada komunitas sains (Nurkhalis, 2012).

Teori kuantum cahaya dipandang kontroversial ketika menggugat otoritas sains yang dianggap telah mapan saat itu. Penerimaan teori kuantum cahaya masih menimbulkan pro dan kontra. Namun dalam perjalanan selanjutnya, banyak gagasan dan fakta-fakta baru hasil eksperimen yang memberikan penguatan terhadap kemapanan teori kuantum cahaya, misalnya seperti ditemukannya emisi termionik, gejala efek Compton, gelombang de Broglie, bahkan hasil eksperimen yang dilakukan oleh Milikan sendiri. Kenyataan ini mendorong semakin banyaknya pengakuan dari masyarakat ilmiah terhadap paradigm baru. Teori kuantum cahaya semakin tak terbantahkan, tidak ada alasan bagi ilmuwan untuk tidak mempercayainya. Masa krisis secara perlahan berakhir, berganti fase sains normal. Perjalanan revolusi telah usai, ditandai dengan terjadinya pergeseran paradigma, dari fisika klasik menuju fisika modern.

Perjalanan penemuan dan perkembangan teori kuantum cahaya sangat bersesuaian dengan fase revolusi saintifik yang dikemukakan oleh Kuhn. Revolusi diawali dengan adanya anomali-anomali pada sains normal yang ditandai dengan munculnya masalah-masalah baru yang tak dapat diselesaikan menggunakan teori yang ada. Kondisi ini disebut fase krisis, hanya dapat diselesaikan menggunakan gagasan-gagasan baru yang revolusioner. Paradigma baru ini membuka pintu baru bagi cakrawala pengetahuan tentang alam. Memberikan pemahaman baru mengenai bagaimana alam bekerja. Paradigma ini mengantarkan dan menuntun aktivitas-aktivitas ilmiah pada sains normal yang baru.

\section{PENUTUP}

Fenomena radiasi benda hitam dan efek fotolistrik membuka gerbang lahirnya teori kuantum cahaya. Telah terjadi pergeseran paradigma (paradigm shift) dalam memahami perilaku cahaya. Teori kuantum cahaya memberikan negasi pada teori gelombang elektromagnetik yang berpegang pada keyakinan bahwa cahaya merambat secara malar dengan kerapatan laju energi yang 
direpresentasikan oleh intensitasnya. Teori kuantum cahaya secara meyakinkan telah menghasilkan gagasan terverifikasi bahwa cahaya terdiri atas paket-paket energi yang diskret, disebut kuanta (foton). Jumlah foton per satuan luas penampang per satuan waktu sebanding dengan intensitas cahaya, tetapi energi foton tidak bergantung pada intensitas cahaya, melainkan hanya bergantung pada frekuensi atau panjang gelombang cahaya.

Mekanika kuantum yang saat ini tengah berkembang pesat tentu tidak akan atau bahkan mustahil terjadi jika tak terjadi pergeseran paradigma tentang prilaku cahaya. Fenomena radiasi benda hitam dan efek fotolistrik secara nyata telah membuka gerbang era fisika modern yang dituntun oleh teori kuantum cahaya. Fenomena ini telah memberikan konsep kunci lahirnya revolusi saintifik, dari teori gelombang elektromagnetik menuju teori kuantum cahaya, dari paradigma fisika klasik menuju paradigma fisika modern. Transformasi-transformasi paradigma yang berurutan dari paradigma yang satu ke paradigma yang lainnya melalui revolusi merupakan pola perkembangan yang biasa dari sains yang matang.

\section{DAFTAR PUSTAKA}

Beiser, A. (1981). Fisika Modern. Terjemahan The Houw Liong. Jakarta: Erlangga

Firman, H. (2016). Perkembangan IImu. Bahan Kuliah Filsafat IImu. Tidak Diterbitkan. Bandung: SPs UPI.

Gie, T.I, et al. (1998). Fisika Modern. Jakarta: Departemen Pendidikan Nasional.

Hamdani. (2011). Filsafat Sains. Bandung: CV Pustaka Setia.

Khun, T.S. (1989). The Structure of Scientific Revolutions: Peran Paradigma dalam Revolusi Sains. Terjemahan Tjun Sujarman. Bandung: Remaja Rosdakarya.

Krane, K.S. (1992). Fisika Modern. Terjemahan Hans J. Wospakrik. Jakarta: Universitas Indonesia Press.

Nahrul, A. (2010). Beberapa Konsep Kunci Pemikiran Thomas Kuhn. Makalah. Tidak diterbitkan.

Nurkhalis. (2012). Konstruksi Teori Paradigma Thomas S. Kuhn. Jurnal IImiah Islam Futura, Volume XI, No. 2, hal 79-99.

Yeremias, J. (2012). Thomas Khun: Perkembangan Sains dan Kritik Larry Laudan. J. Melintas 28(2): 161-181.

Zubaedi, et al. (2007). Filsafat Barat: dari Logika Baru Rene Descartes hingga Revolusi Sains ala Thomas Kuhn. Yogyakarta: Ar-Ruzz Medi. 